\title{
Geoengineering conditions of the environmental protection facilities in the centre of the Oder River
}

\author{
Magda Hudak $^{1}$, Urszula Kołodziejczyk ${ }^{1}$, Jakub Kostecki ${ }^{1, *}$ \\ ${ }^{1}$ University of Zielona Góra, Faculty of Civil Engineering, Architecture and Environmental \\ Engineering; 15 Prof. Szafrana St., 65-516 Zielona Góra, Poland
}

\begin{abstract}
The ongoing management of river valleys has had a negative impact on the effectiveness of flood protection of former floodplains. The risk of flooding and flood damage is constantly increasing. As a result of disorganized industrialization, we are dealing with the accumulation of precipitation which flows much faster from the catchment area to the main river. In turn, due to erosion and the sedimentation processes, the capacity of the main river bed and its tributaries is limited. The solution to the problem may be multidirectional flood control measures, which were designed for the Lubuskie part of the Oder River, from Nowa Sól to Milsko. They concern: the construction of a flood wall in Nowa Sól, the modernization of the flood embankments in the Nowa Sol area and reconstruction of the former floodplain in Milsko. The paper presents the geoengineering conditions of these projects.
\end{abstract}

\section{Introduction}

In recent years, despite impressive technical achievements, there has been a noticeable increase in flood risks. This results from economic and social pressure, which has forced the increasing development of flood plains. In the Oder River basin, an infamous example is the flood of July 1997, which exceeded all the "high waters" so far. Climate change is one of the causes of rapid flooding, which occur more and more frequently in the world [1, 2]. However, it is possible to notice an approach that consists in increasing social sensitivity (education) and using technical solutions, reducing the negative impact of floods on people's life and health and the environment $[3,4,5]$. In the case of the Oder River valley, another factor that led to the "Millennium Flood" was the neglected flood protection system that needed modernization. In 1997, $3.57 \mathrm{~km}$ of embankments in the middle section of the Oder River were washed out and the same number of objects were severely deformed [6, 7]. An example is the Nowa Sól-Milsko section, where the embankments were broken in 11 places. In the following years, the condition of flood protection facilities progressively deteriorated as a result of high water, erosion processes and improper use $[8,9,10]$.

In the years 1999-2016, $159.43 \mathrm{~km}$ of embankments, $341.25 \mathrm{~km}$ of channels and rivers, 14 pumping stations and 7 retention tanks were rebuilt in the Oder River basin. Further

\footnotetext{
* Corresponding author: j.kostecki@iis.uz.zgora.pl
} 
actions are planned, for example, the establishment of a centre for monitoring pump stations in Lubusz Voivodeship. It is expected that this will enable the remote control of selected devices in the pumping stations, which will greatly improve the control of "high water".

In order to effectively protect areas against flooding, further integrated measures are necessary, which are required after the adoption of the Flood Directive [11]. An example of an area where such measures have been taken can be the Oder River basin, where, apart from the classical embankments, additional solutions are used such as flood polders, retention tanks and relief channels.

\section{Flood protection in the Middle Oder Valley}

Flood protection of the middle section of the Oder River consists of: embankments, polders, retention tanks and relief channels. An example is the Nowa Sól-Milsko section (Fig. 1), where current flood protection consists of embankments, a flood wall and the historic Milsko flood plain polder.

Polders are a form of flood protection that stops a certain amount of flood waters and reduces the peak flow of rivers during freshets. Before World War 1, there were 12 polders in the Oder River basin with a total area of 12.7 thousand ha and a capacity of 104.6 million $\mathrm{m}^{3}$. At present, there are 10 polders there, with a flood area of 6.4 thousand ha and a retention capacity of 75 million $\mathrm{m}^{3}$. During floods, they are flooded through inlet sluices or by embankment overflows. All objects were established at the beginning of the 20th century. Nowadays, most of them are not used as intended - they are often agricultural or built-up areas $[12,13]$.

Polders are only effective on condition that there is coherent water management in the entire basin. They reduce possible economic losses that may result from water shortages, while at the same time improve the structure of the water balance. A good example could be the restoration of the flood polders built by German engineers that still existed in the middle section of the Oder River in the 1940s and 1950s. They are: Milsko (300 ha), Tarnawa (220 ha), Pomorsko (200 ha), Brody-Bródki (180 ha), Nietkowice (310 ha), Będów (180 ha) and Połupin-Szczawno-Laski (2800 ha ). At present, the following polders exist in the middle section of the Oder River: Kiełcz-Tarnów Bycki (815 ha), Połupin (4125 ha) and Krzesin-Bytomiec (1200 ha). In the "Oder River Programme" further projects are planned: Urad (30 million $\left.\mathrm{m}^{3}\right)$, Słubice Górzyca $\left(60\right.$ million $\left.\mathrm{m}^{3}\right)$ and Ługi Górzyckie (30 million $\mathrm{m}^{3}$ ) - Fig. 1 . 


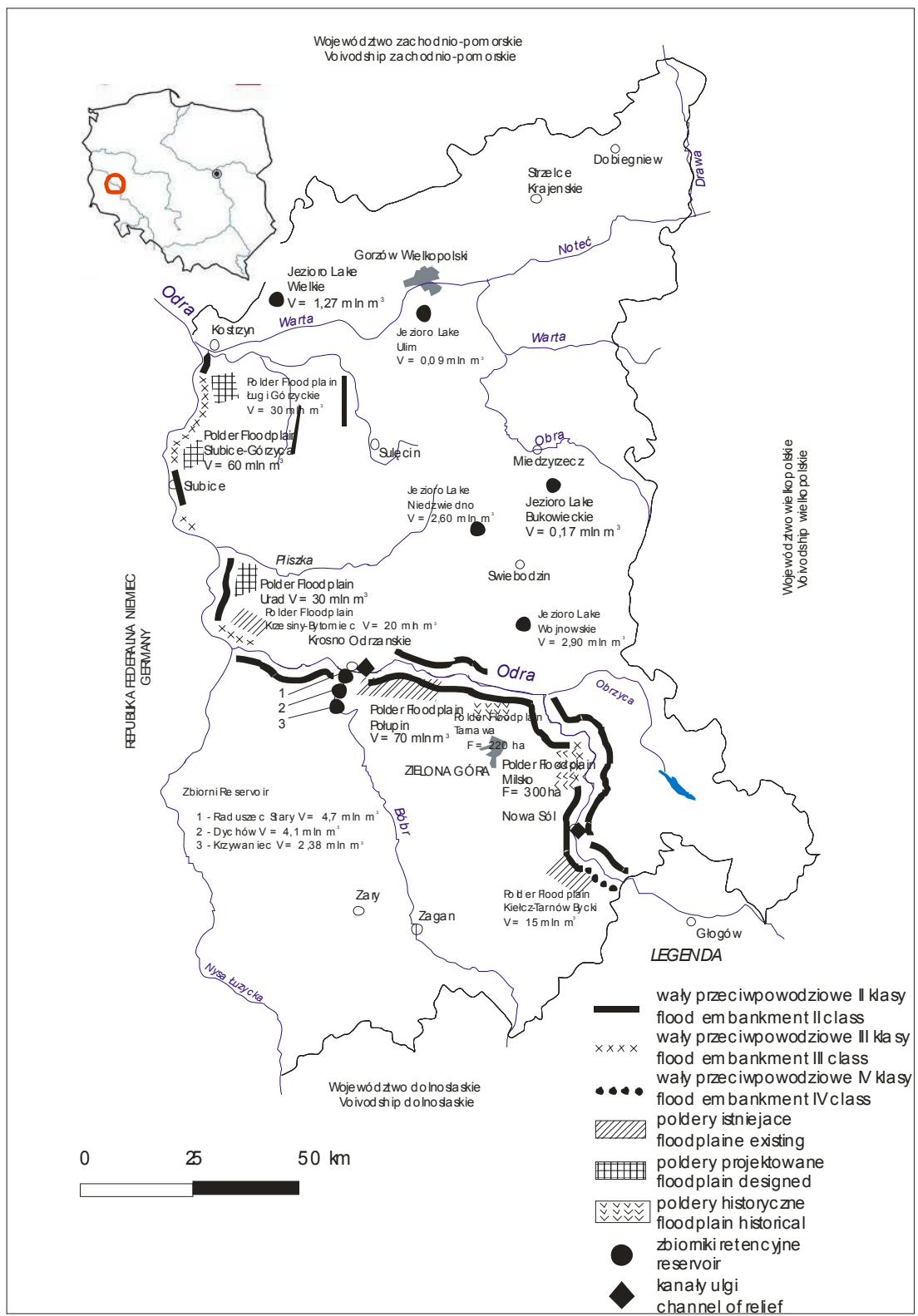

Fig. 1. Flood protection facilities of the central Odra.

\section{Geological and engineering research in the Milsko polder area}

The historical Milsko polder (Photo 3) is located in the Nowa Sól-Milsko section. The area is currently used for agriculture. It is drained through the Jasieniec watercourse - at the mouth of the watercourse there is a pumping station that directs the water to the channel and the Jasieniec reservoir, and then to the Oder River. 


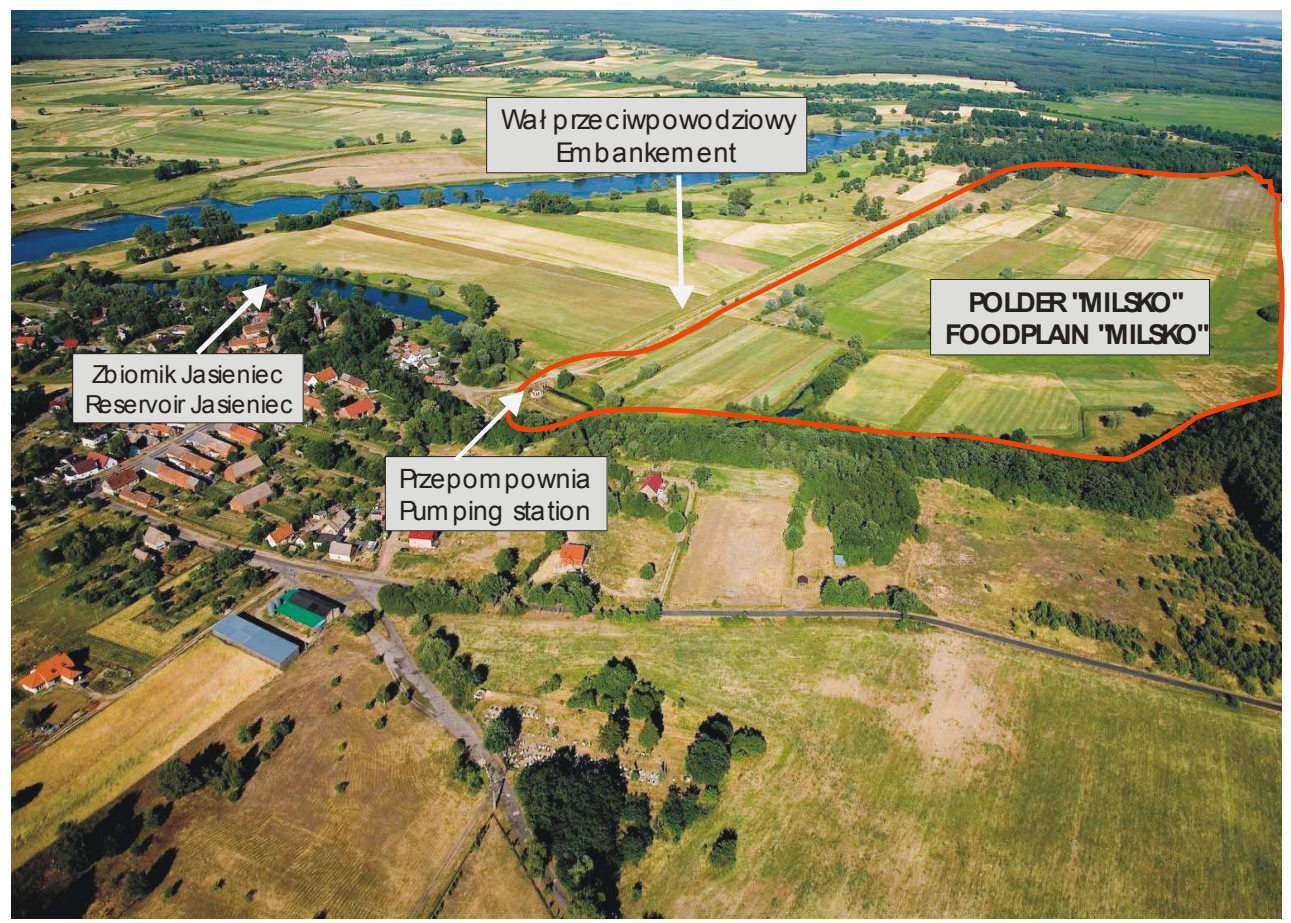

Pic. 1. Floodplain „Milsko”.

The recreation of the Milsko polder as a controlled dry reservoir provides an opportunity to manage flood waters in an area of around 300 ha (with a capacity of 10 million $\mathrm{m}^{3}$ ). The polder was designed between a natural slope (the terminal moraine of the North Polish glaciation) and the Oder River embankment.

In order to identify the geological structure of the polder embankment on the Oder River side, small-diameter drillings were performed to a depth of $6 \mathrm{~m}$. Soil samples obtained from the drillings were examined for particle size distribution, then soil texture and the filtration coefficient were determined (according to the Hazen formula). On the basis of the identified geological structure of the embankments, water filtration through the embankment towards the tank was calculated in five research cross-sections (Fig.2). It was assumed that during periodical water pile-ups at the embankment, filtration would be unspecified or specified in character. The first situation will occur during rapid rises and falls of the water table, but when a particular water level has been stable for a relatively long time, the flow conditions will be stabilized and the specified filtration will occur (14).

The geological research carried out showed that the embankment was built of cohesionless soils, such as: medium sands (MSa), fine sands (FSa), loamy sands (clSa), silty sands (siSa) and cohesive soils: clays (sasiCL) and sandy loams (clSa). It was assumed in the calculations that the process of filtration would occur through an unsealed embankment, with a poorly permeable bed, and the water column would correspond to 100year water $(\mathrm{Q} 1.0 \%)$ and 300-year water $(\mathrm{Q} 0.3 \%)$. In the calculations of the flow rate, simplifications were made (as suggested by Dupuit) that assumed horizontal current lines and horizontal components of the hydraulic gradient corresponded to the slope of the depression line $(15,16)$. The geological structure of the embankment was analysed and the location of the depression line was determined for each of the cross-sections analysed, which made it possible to calculate the unit flow of water through the unsealed embankment (17). 
It was assumed that the pile-up state usually lasts for 3-4 days. During this time the water should not filter through the embankment. The risk of damage to the structure of the embankment increases when the pile-up state lasts for a long time. On the basis of the calculations of filtration curves, the time of the water flow (filtration) through the unsealed embankment was calculated, which for the water flow with a height of the water column corresponding to Q1.0\% is from 2.40 to 4.85 days, respectively. However, for the water flow with a height of the water column corresponding to Q $0.3 \%$, it ranges between $2.19 \div$ 4.35 days - Table 1.

Table 1. Calculating the flow time of water (filtration) through an unshielded shaft.

\begin{tabular}{|c|c|c|}
\hline \multirow{2}{*}{$\begin{array}{c}\text { Cross section of flood } \\
\text { embankment }\end{array}$} & $\begin{array}{c}\text { Total time of water flow through the shaft unsealed at the height } \\
\text { of the corresponding water column }\end{array}$ \\
\cline { 2 - 3 } & $\mathbf{Q}_{\mathbf{1 , 0} \%}$, day & $\mathbf{Q}_{\mathbf{0}, \mathbf{3} \%}$, day \\
\hline I-I' $^{\prime}$ & 3.18 & 2.82 \\
\hline IIII' $^{\prime}$ & 3.10 & 2.75 \\
\hline IV-II' $^{\prime}$ & 4.85 & 4.35 \\
\hline $\mathrm{V}^{\prime} \mathrm{V}^{\prime}$ & 2.40 & 2.19 \\
\hline
\end{tabular}

The total time of the water flow through the embankment under research is close to the boundary time of water retention by the embankment, which is approx. 4 days. This result may indicate leakage in the embankment, and when flood water is contained longer than the 4-day retention time, it means that the flood embankment might be completely destroyed.

\section{Summary}

The accumulated effects of the inadequate maintenance of river valleys, changes in catchment development and disordered industrialization make rainwater flow from the catchment area to the main river much faster. There is also the problem of climate change and adaptation to it, which is noticed more and more frequently $(2,18)$. As a result of erosion and sedimentation processes, the capacity of the main riverbeds and their tributaries is limited. As human settlements expand into floodplains, the risk of flooding increases and the effects of measures taken to repair damage are greater.

The construction of embankments is commonly accepted as an effective method of flood protection. These structures become larger as the river changes from meandering to braided, the floodplains undergo development, and the inter-embankment area becomes narrower. Meanwhile, it would be good to return to old solutions and - among other things - to recreate old floodplain polders. An integrated approach to the problem makes it possible to achieve better results in a much shorter time $(19,20)$.

In order to reach a compromise between the main objective of construction of embankments, which is to protect human life, and hydrological and environmental requirements, it necessary to strictly follow the design and construction rules that are required. The flood wave should be allowed to spill over certain areas because this will flatten it. Wherever it is feasible, the embankments should be located at the greatest possible distance from the river bed. This increases the capacity of the inter-embankment area and water retention in the river valley, and also reduces the level of freshets and the flow rate of flood waters.

Inspection of the condition of embankments is one of the most important tasks in flood prevention. It should be carried out systematically at least once every five years, regardless of the frequency of flooding, the level of modernization of the embankments or the method used to repair them. 
Identification of the condition of embankments makes it possible to improve the effectiveness of flood protection both by piling up water in the inter-embankment area and by indicating additional solutions, such as the restoration of historic polders and the renaturalization of the river valley.

\section{References}

1. H. Mo Madsen, R .Brown, M. Elle, P.S. Mikkelsen. Technological Forecasting \& Social Change. 115, 198-209 (2017)

2. M.I. Mahmood, N.A. Elagib, F. Horn, S.A.G. Science of the Total Environment. 601602, 1031-1045 (2017)

3. K. Bhattacharjee, B. Behera Land Use Policy. 67, 436-448 (2017)

4. Brown, J., Damery, L. Trans. Inst. Br. Geograph. 27 (4), 412-426 (2002)

5. Conrad, C., Daoust, T. Environ. Manag. 41, 358-366 (2008)

6. U. Kołodziejczyk. Zeszyty Naukowe Uniwersytetu Zielonogórskiego - Budownictwo. 129, $75-87$ (2002)

7. U. Kołodziejczyk. Civil and Environmental Engineering Reports. 2, 37-47 (2007)

8. U. Kołodziejczyk, A. Asani. Gospodarka Wodna, 8, 337-342 (2012)

9. F. Saathoff, K. Werth. Geokunststoffe in Dämmen und Dei-chen.Sicherung von Dämmen und Deichen: Handbuch für Theorie und Pra-xis. Hrsg. Hermann und Jensen. Universitätsverlag Siegen. 221 - 237 (2003)

10. M. Topolnicki. Herstellung von Dichtwänden in alten Deichen in Polen mit dem Verfahren der tiefen Bodenvermörtelung (DMM). Bemessungsana-lysen und Ausführungsbeispiele. Fachaufsatz. D. Keller Grundbau GmbH. 32 - 51 (2003)

11. Dyrektywa 2007/60/WE Parlamentu Europejskiego i Rady z dn. 23 października 2007 $r$. w sprawie oceny ryzyka powodziowego i zarzadzania nim

12. W. Majewski. Materiały Seminarium „Nowe podejście do zagadnień ochrony przeciwpowodziowej”. IBW PAN (2004)

13. W. Mioduszewski. Przegląd Naukowy Inżynieria i Kształtowanie Środowiska. 31, 2005.

14. T. Strzelecki, S. Kostecki, S. Żak Modelowanie przepływów przez ośrodki porowate. DSWE (2008)

15. M. Borys, K. Mosiej. Wytyczne wykonywania oceny stanu technicznego i bezpieczeństwa wałów przeciwpowodziowych. Wyd. IMUZ, Falenty (2003)

16. M. Borys, K. Mosiej. Oceny stanu technicznego obwałowań przeciwpowodziowych. Wyd. IMUZ, Falenty (2008)

17. M. Hudak, U. Kołodziejczyk, I. Nowogoński. Gospodarka Wodna, 12, 402-406 (2017)

18. N. Suckall, E. L. Tompkins, R.J. Nicholls, A.S. Kebede, A.N. Lázár, C. Hutton, K. Vincent, A. Allan, A. Chapman, R. Rahman, T. Ghosh, A. Mensah. Science of the Total Environment. 633, 946-957 (2018)

19. N.B. Chang, J.W. Lu, T.F.M. Chui, N. Hartshorn. Land Use Policy. 70, 368-383 (2018)

20. C. Kuklicke, D. Demeritt. Global Environmental Change. 37, 56-68 (2016) 